\title{
Evaluating the psychometric properties of an e-based version of the 39-item Parkinson's Disease Questionnaire
}

\author{
David Morley*, Sarah Dummett, Laura Kelly, Jill Dawson and Crispin Jenkinson
}

\begin{abstract}
Background: The 39-item Parkinson's Disease Questionnaire (PDQ-39) is the most thoroughly validated and extensively used self-report measure for the assessment of health-related quality of life in people with Parkinson's (PwP). Given the extent of its use and increasing emphasis on electronic data capture, an e-based version of the PDQ-39, the ePDQ, has recently been developed. The aim of this short report is to present some key reliability and validity data that confirm the psychometric quality of the ePDQ.
\end{abstract}

Findings: Participants were emailed a unique link to an online survey incorporating the ePDQ and demographic questions. A total of 118 PwP fully completed the survey. Floor and ceiling effects were calculated to ensure responses were not biased to extreme values. Consequently, score reliability was assessed by item-total correlations with a range from 0.34 to 0.90 . Cronbach's alpha was calculated at between 0.64 and 0.95 for the eight domains of the ePDQ. Construct validity was assessed by comparing domain scores in relation to disease duration and gender, with hypothesised differences being largely confirmed. Construct validity was further assessed following a higher order factor analysis which confirmed the appropriateness of calculating a summary index score. Subsequently, significant, but moderate correlations were calculated between the ePDQ summary index score and disease duration and age at diagnosis.

Conclusions: Results indicate that the ePDQ largely mirrors the properties of its parent instrument, the PDQ-39, in terms of reliability and validity. Potential users can therefore incorporate the ePDQ into computer-based data capture systems with confidence.

Keywords: PDQ-39, Parkinson's disease questionnaire, e-based, ePDQ, Electronic patient reported outcomes, ePROs, Reliability, Validity

\section{Introduction}

The 39-item Parkinson's Disease Questionnaire (PDQ39) [1] is the most thoroughly validated and extensively used self-report measure for the assessment of healthrelated quality of life in people with Parkinson's (PwP) [2]. The measure has been shown to possess sound psychometric properties [1,3-6] and its use is widely recommended $[2,7,8]$. Given the extent of its use and the increasing emphasis on electronic data capture [9-12], an electronic version of the PDQ-39, the ePDQ, has recently been developed. The acceptability and usability of the ePDQ have previously been reported, alongside a study assessing the impact of implementing non-response options versus 'forced response' on response rates and data completeness [13].

It has been suggested that full-scale psychometric analysis is not strictly necessary when developing electronic patient reported outcomes (ePROs) which closely mirror their paper-based equivalent [14]. However, given the extensive use of the PDQ-39, potential users of the electronic version may require reassurance that its psychometric properties are consistent with those of the paper-based version. The aim, therefore, of this short report is to present some key reliability and validity data that confirm the psychometric quality of the ePDQ.

\footnotetext{
* Correspondence: david.morley@dph.ox.ac.uk

Health Services Research Unit, Nuffield Department of Population Health, University of Oxford, Old Road Campus, Oxford OX3 7LF, UK
}

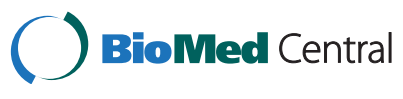

(C) 2015 Morley et al.; licensee BioMed Central. This is an Open Access article distributed under the terms of the Creative Commons Attribution License (http://creativecommons.org/licenses/by/4.0), which permits unrestricted use, distribution, and reproduction in any medium, provided the original work is properly credited. The Creative Commons Public Domain Dedication waiver (http://creativecommons.org/publicdomain/zero/1.0/) applies to the data made available in this article, unless otherwise stated. 


\section{Materials and methods}

Ethical approval for the study was granted by the Medical Sciences Inter Divisional Research Ethics Committee of the University of Oxford (reference MSD-IDREC-C1-2013-17).

\section{Participants}

Recruitment of participants was undertaken with the support of Parkinson's UK. Study details were distributed by the charity's Research Communications Office to their research support network across the United Kingdom. Potential participants were requested to contact the research team by telephone or email.

\section{Materials}

The ePDQ [13], an electronically administered version of the PDQ-39 [1] was administered using Qualtrics survey software [15]. The measure totals 39 items, assessing eight domains of health; Mobility, Activities of Daily Living, Emotional Well-Being, Stigma, Social Support, Cognitions, Communication and Bodily Discomfort. Domain scores are coded on a scale of 0 (perfect health as assessed by the measure) to 100 (worst health as assessed by the measure). A summary index score can subsequently be calculated from the eight domains outlined above [16]. Demographic data (gender, age, marital status, ethnic origin and age at or year of diagnosis) were obtained after participants had completed the ePDQ items.

\section{Procedure}

After contacting the research team, participants were emailed a unique link to the online survey which could be completed in their own time and at a location of their choice (e.g. home, workplace). A follow-up email was sent after two weeks to non-responders.

\section{Statistical analysis}

Data was checked for normality of distribution and presence of outliers prior to statistical analysis. Floor and ceiling effects were calculated for each domain of the ePDQ. Reliability was assessed via corrected item-total correlations and Cronbach's alpha. Validity was determined through calculation of differences between known groups using independent samples t-tests. Higher order factor analysis was used to create a summary index score. Relationships between the summary index score and relevant demographic variables were tested via Pearson correlations coefficients in order to further assess validity.

\section{Results}

A total of 118 PwP (66 males, 52 females) fully completed the ePDQ, a response rate of $91.4 \%$. The mean age was 63.48 years (standard deviation (SD) 8.66), mean disease duration 5.73 years (SD 4.34) and mean age at diagnosis 57.69 years (SD 9.00).

\section{Reliability}

Floor and ceiling effects were calculated to ensure responses were not biased to extreme values (see Table 1). Consequently score reliability was assessed by item-total correlations (also reported in Table 1) with a range from 0.34 to 0.90 . Cronbach's alpha was calculated at between 0.64 and 0.95 for the eight domains of the ePDQ, indicating sufficient to excellent internal reliability. Alpha values for all domains can again be viewed in Table 1 .

\section{Validity}

Construct validity was assessed by comparing domain scores in relation to disease duration (groups split based on median disease duration of 4 years) and gender, as seen in Table 2. All domains anticipated as being significantly different for disease duration were confirmed as such; Mobility; Activities of Daily Living; Cognitive Impairment; Communication; Bodily Discomfort. Hypothesised nonsignificant differences between males and females were confirmed in all but one of the eight ePDQ domains. Construct validity was further assessed following a higher order factor analysis which confirmed the appropriateness of calculating a summary index score. One factor with an Eigenvalue in excess of one was identified, accounting for $55.4 \%$ of variance (extraction method principal component analysis). Each domain of the ePDQ loaded on this one factor which had an eigenvalue of 4.4. Subsequently, all eight domains of the ePDQ were summed to create the summary index score. The mean value of the summary index was 28.67 (S.D. $=16.66, \min =2.97, \max =91.93$ ). Finally, validity was further established by significant, but moderate correlations between the ePDQ summary index score and disease duration $(\mathrm{r}=.27, \mathrm{p}<0.01)$ and age at diagnosis $(\mathrm{r}=-.27, \mathrm{p}<0.01)$.

\section{Discussion}

This short report has presented a brief analysis of the newly developed $\mathrm{ePDQ}$ as a means of confirming that the measure reflects qualities that are consistent with the paperbased PDQ-39 [1]. Floor and ceiling effects generally mirror those of the parent instrument, largely falling within previously used criteria of $20 \%$ [17]. It is acknowledged, however, that the domain of Social Support is almost double this figure, which may be a reflection of the inherent weakness of three-item domains. Reliability of the ePDQ is confirmed by two commonly used analyses, item-total correlations and Cronbach's alpha values. All item-total correlations are in excess of previously defined criteria [18], the majority significantly so, thereby confirming that item scores within each domain are related to the overall domain score and thus, to the underlying construct. Cronbach's alpha coefficients are above the recommended level of 0.70 in all but one domain, indicating good to excellent internal reliability [19]. The one domain to fall below this figure, Cognitive 
Table 1 ePDQ item-total correlations with domain floor and ceiling effects and Cronbach's alpha values

\begin{tabular}{|c|c|c|c|}
\hline Domain & $\begin{array}{l}\text { Item } \\
\text { no }\end{array}$ & Item & $\begin{array}{l}\text { Item-t } \\
\text { correl } \\
\text { (corre }\end{array}$ \\
\hline \multicolumn{4}{|l|}{ Mobility } \\
\hline & 1 & $\begin{array}{l}\text { Had difficulty } \\
\text { doing leisure } \\
\text { activities }\end{array}$ & 0.69 \\
\hline & 2 & $\begin{array}{l}\text { Had difficulty } \\
\text { looking after your } \\
\text { home }\end{array}$ & 0.76 \\
\hline & 3 & $\begin{array}{l}\text { Had difficulty } \\
\text { carrying bags of } \\
\text { shopping }\end{array}$ & 0.73 \\
\hline & 4 & $\begin{array}{l}\text { Had problems } \\
\text { walking half a mile }\end{array}$ & 0.86 \\
\hline & 5 & $\begin{array}{l}\text { Had problems } \\
\text { walking } 100 \text { yards }\end{array}$ & 0.87 \\
\hline & 6 & $\begin{array}{l}\text { Had problems } \\
\text { getting around the } \\
\text { house }\end{array}$ & 0.84 \\
\hline & 7 & $\begin{array}{l}\text { Had difficulty } \\
\text { getting around in } \\
\text { public places }\end{array}$ & 0.90 \\
\hline & 8 & $\begin{array}{l}\text { Needed to be } \\
\text { accompanied } \\
\text { when out }\end{array}$ & 0.78 \\
\hline & 9 & $\begin{array}{l}\text { Frightened or } \\
\text { worried about } \\
\text { falling in public }\end{array}$ & 0.67 \\
\hline & 10 & $\begin{array}{l}\text { Been confined to } \\
\text { the house more } \\
\text { than liked }\end{array}$ & 0.82 \\
\hline
\end{tabular}

Activities of daily living

\begin{tabular}{|c|c|}
\hline 11 & $\begin{array}{l}\text { Had difficulty } \\
\text { washing yourself }\end{array}$ \\
\hline 12 & $\begin{array}{l}\text { Had difficulty } \\
\text { dressing yourself }\end{array}$ \\
\hline 13 & $\begin{array}{l}\text { Had problems } \\
\text { doing up buttons } \\
\text { or laces }\end{array}$ \\
\hline 14 & $\begin{array}{l}\text { Had problems } \\
\text { writing clearly }\end{array}$ \\
\hline 15 & $\begin{array}{l}\text { Had difficulty } \\
\text { cutting up food }\end{array}$ \\
\hline 16 & $\begin{array}{l}\text { Had difficulty } \\
\text { holding a drink }\end{array}$ \\
\hline
\end{tabular}

Emotional well-being

$\begin{array}{lll}17 & \text { Felt depressed } & 0.71 \\ 18 & \begin{array}{l}\text { Felt isolated and } \\ \text { lonely }\end{array} & 0.80 \\ 19 & \text { Felt weepy or } & 0.72\end{array}$ tearful correlation Floor Ceiling (corrected)

69

$\begin{array}{lll}1.7 & 4.2 & 0.95\end{array}$

.86

$0.8 \quad 1.7 \quad 0.88$

$\begin{array}{lll}0.8 & 5.9 & 0.88\end{array}$

Table 1 ePDQ item-total correlations with domain floor and ceiling effects and Cronbach's alpha values

(Continued)

$\begin{array}{lll}20 & \text { Felt angry or bitter } & 0.67 \\ 21 & \text { Felt anxious } & 0.63 \\ 22 & \begin{array}{l}\text { Felt worried about } \\ \text { the future }\end{array} & 0.68 \\ & \end{array}$

Stigma

23 Felt you had to conceal PD from people

24 Avoided eating or drinking in public

25 Felt embarrassed by having PD

26 Felt worried by other's reaction to you

Social support

$27 \quad$ Had problems with 0.58 close relationships

$28 \quad$ Not had support $\quad 0.66$ from spouse or partner

29 Not had support from friends or family

\section{Cognitive impairment}

hallucinations

Communication

Bodily discomfort
30 Unexpectedly fallen 0.38 asleep during day

31 Had problems with 0.59 concentration

32 Felt your memory 0.40 was bad

33 Had distressing $\quad 0.35$

dreams or

$\begin{array}{lll}0.8 & 21.2 & 0.87\end{array}$

$34 \begin{aligned} & \text { Had difficulty with } \\ & \text { speech }\end{aligned}$

35 Felt unable to $\quad 0.82$ communicate properly

36 Felt ignored by $\quad 0.67$ people

$0.8 \quad 6.8$ 0.71

$0.8-17=0.64$

\begin{tabular}{|c|c|c|}
\hline 37 & $\begin{array}{l}\text { Had painful muscle } \\
\text { cramps or spasms }\end{array}$ & 0.60 \\
\hline 38 & $\begin{array}{l}\text { Had aches and } \\
\text { pains }\end{array}$ & 0.58 \\
\hline 39 & $\begin{array}{l}\text { Felt unpleasantly } \\
\text { hot or cold }\end{array}$ & 0.41 \\
\hline
\end{tabular}


Table 2 Comparison of ePDQ domains by disease duration and gender

\begin{tabular}{|c|c|c|c|c|c|c|}
\hline & \multicolumn{2}{|c|}{ Disease duration } & \multirow[b]{2}{*}{$p$} & \multicolumn{2}{|l|}{ Gender } & \multirow[b]{2}{*}{$p$} \\
\hline & $\begin{array}{l}1-4 \text { years } \\
(n=59)\end{array}$ & $\begin{array}{l}5-20 \text { years } \\
(n=59)\end{array}$ & & $\begin{array}{l}\text { Male } \\
(n=66)\end{array}$ & $\begin{array}{l}\text { Female } \\
(n=52)\end{array}$ & \\
\hline Mobility & $27.03(26.87)$ & $41.27(25.47)$ & $<.00$ & $31.86(25.59)$ & $37.07(28.73)$ & NS \\
\hline Activities of daily living & $28.11(21.86)$ & $39.62(24.15)$ & $<.00$ & $33.58(23.01)$ & $34.21(24.67)$ & NS \\
\hline Emotional well-being & $26.20(21.16)$ & $32.06(20.10)$ & NS & $26.83(20.87)$ & $32.05(20.45)$ & NS \\
\hline Stigma & $17.58(19.37)$ & $24.68(23.31)$ & NS & $19.51(21.19)$ & $23.20(22.22)$ & NS \\
\hline Social support & $14.12(21.84)$ & $15.34(17.12)$ & NS & $17.30(21.45)$ & $11.70(16.52)$ & NS \\
\hline Cognitive impairment & $25.53(18.29)$ & $32.84(17.96)$ & $<.05$ & $29.45(17.36)$ & $28.85(19.85)$ & NS \\
\hline Communication & $22.88(23.14)$ & $33.05(25.85)$ & $<.05$ & $32.07(23.03)$ & $22.76(26.51)$ & $<.05$ \\
\hline Bodily discomfort & $35.17(23.67)$ & $47.17(24.05)$ & $<.00$ & $38.13(24.98)$ & $45.03(23.58)$ & NS \\
\hline
\end{tabular}

(standard deviation; NS = non-significant).

Impairment at 0.64 , remains above the level regarded as sufficient [20].

The validity of the ePDQ was confirmed via a number of analyses. Firstly, a comparison of known groups was made, (sometimes referred to as known groups validity). Such an assessment is made where there are good reasons to hypothesise that scores on a construct being measured will differ between two groups [21], as has been addressed in previous research [22,23]. When comparing domains by disease duration those hypothesised as being significantly different were confirmed (Mobility, Activities of Daily Living, Cognitive Impairment, Communication and Bodily Discomfort). The three domains of Emotional Well-Being, Stigma and Social Support are deemed not to be as sensitive to disease duration with results appearing to support this. Additionally, nonsignificant differences between males and females were observed in seven of the eight ePDQ domains. Construct validity was further supported through the use of a higher order factor analysis to confirm the appropriateness of summing domain scores to create a summary index score. This technique has been widely used in previous research [16,24-27]. Summary index scores were found to correlate significantly, and in the anticipated direction, with relevant demographic variables to provide further evidence of validity.

It is acknowledged that this study may be limited by the relatively small sample size, although this is adequate for the analyses reported. It is, however, recommended that the ePDQ be further assessed in larger surveys and over time in longitudinal studies. Assessment of the sensitivity of the ePDQ is also required, although given that the reliability and validity of the measure largely mirrors that of the paper-based version, it is anticipated that sensitivity data should follow a similar pattern. Additionally it is acknowledged that the sample reported here may not be entirely representative of the Parkinson's population at large, as not all PwP will have access to electronically administered measures or be computer literate.

In conclusion, data indicates that the ePDQ possesses appropriate levels of reliability and validity and can be incorporated into studies with confidence by those who wish to do so. Should readers wish to make direct comparisons between the psychometric properties of the PDQ-39 and ePDQ they can do so via the data presented here and the original validation paper for the PDQ-39 [1] or current user manual [6]. Further details of the ePDQ, the PDQ-39 and other related measures, along with how to obtain copies, can be obtained from DM or CJ.

\section{Abbreviations}

ePDQ: Electronic Parkinson's Disease Questionnaire; ePROs: Electronic patient reported outcomes; PDQ39: 39-Item Parkinson's Disease Questionnaire; PWP: People with Parkinson's; SD: Standard deviation.

\section{Competing interests}

$\mathrm{CJ}$ is a developer of the PDQ-39 and receives royalties from its use. DM, LK and JD have all undertaken consultancy work for ISIS Outcomes who hold the license for the PDQ-39. SD has no conflict of interest to report.

\section{Authors' contributions}

DM contributed to the study design, conducted the statistical analyses and drafted the manuscript. SD collected data and managed the study on a daily basis. LK designed the electronic questionnaire. JD contributed to the study design. CJ developed the study design and was the principal investigator. All authors read and approved the final manuscript.

\section{Acknowledgements}

We would like to thank Parkinson's UK and the many people with Parkinson's who participated in this research for their support.

\section{Funding}

This study was internally funded.

Received: 25 September 2014 Accepted: 15 December 2014 Published online: 23 January 2015

\section{References}

1. Peto V, Jenkinson C, Fitzpatrick R, Greenhall R. The development of a short measure of functioning and well being for individuals with Parkinson's disease. Qual Life Res. 1995;4:241-8. 
2. Martinez-Martin P, Jeukens-Visser M, Lyons K, Rodriguez-Blazquez C, Selai C, Siderowf A, et al. Health-related quality-of-life scales in Parkinson's disease: critique and recommendations. Mov Disord. 2011;26:2371-80.

3. Peto V, Jenkinson C, Fitzpatrick R. PDQ-39: a review of the development, validation and application of a Parkinson's disease quality of life questionnaire and its associated measures. J Neurol. 1998;245 Suppl 1:10-4.

4. Fitzpatrick R, Jenkinson C, Peto V, Hyman N, Greenhall R. Desirable properties for instruments assessing quality of life: evidence from the PDQ-39. J Neurol Neurosurg Psychiatry. 1997;62:104.

5. Peto $V$, Jenkinson $C$, Fitzpatrick $R$. Determining minimally important differences for the Parkinson's disease questionnaire (PDQ-39). Age Ageing 2001;30:299-302

6. Jenkinson C, Fitzpatrick R, Peto V, Dummett S, Morley D, Saunders P. The Parkinson's Disease Questionnaire: User Manual. 3rd ed. Oxford: Isis Outcomes; 2012

7. McGhee D, Parker A, Fielding S, Counsell C. Which clinical measures are most appropriate for measuring disease progression in Parkinson's disease? J Neurol Neurosurg Psychiatry. 2013;84:e2.

8. Marinus J, Ramaker C, van-Hilten JJ, Stiggelbout AM. Health related quality of life in Parkinson's disease: a systematic review of disease specific instruments. J Neurol Neurosurg Psychiatry. 2002;72:241-8.

9. Shah J, Rajgor D, Pradhan S, McCready M, Zaveri A, Pietrobon R. Electronic data capture for registries and clinical trials in orthopaedic surgery: open source versus commercial systems. Clin Orthop Relat Res. 2010;468:2664-71.

10. Bennett AV, Jensen RE, Basch E. Electronic patient-reported outcome systems in oncology clinical practice. CA Cancer J Clin. 2012;62:337-47.

11. Holzner B, Giesinger JM, Pinggera J, Zugal S, Schöpf F, Oberguggenberger AS, et al. The Computer-based Health Evaluation Software (CHES): a software for electronic patient-reported outcome monitoring. BMC Med Inform Decis Mak. 2012;12:126.

12. Zbrozek A, Hebert J, Gogates G, Thorell R, Dell C, Molsen E, et al. Validation of electronic systems to collect patient-reported outcome (PRO) data-recommendations for clinical trial teams: report of the ISPOR ePRO systems validation good research practices task force. Value Health. 2013;16:480-9.

13. Morley D, Dummett S, Kelly L, Dawson J, Jenkinson C. An electronic version of the PDQ-39: acceptability to respondents and assessment of alternative response formats. J Parkinsons Dis. 2014:4:467-72.

14. Coons SJ, Gwaltney CJ, Hays RD, Lundy JJ, Sloan JA, Revicki DA, et al. Recommendations on evidence needed to support measurement equivalence between electronic and paper-based patient-reported outcome (PRO) measures: ISPOR ePRO good research practices task force report. Value Health. 2009;12:419-29.

15. Qualtrics (2005) Qualtrics. 37,892 ed. Provo, Utah, USA: Qualtrics Research Suite.

16. Jenkinson C, Fitzpatrick R, Peto V, Greenhall R, Hyman N. The Parkinson's disease questionnaire (PDQ-39): development and validation of a Parkinson's disease summary index score. Age Ageing. 1997;26:353-7.

17. Hobart JC, Riazi A, Lamping DL, Fitzpatrick R, Thompson AJ. Improving the evaluation of therapeutic interventions in multiple sclerosis: development of a patient-based measure of outcome. Health Technol Assess. 2004;8(9):iii. 1-48.

18. Estabrooks CA, Squires JE, Hayduk LA, Cummings GG, Norton PG. Advancing the argument for validity of the Alberta Context Tool with healthcare aides in residential long-term care. BMC Med Res Methodol. 2011;11:107.

19. Scientific Advisory Committee of the Medical Outcomes Trust. Assessing health status and quality of life instruments: attributes and review criteria. Qual Life Res. 2002;11:193-205.

20. Helmstater G. Principles of Psychological Measurement. New York: Appleton 1964.

21. Brazier J, Deverill M. A checklist for judging preference-based measures of health related quality of life: learning from psychometrics. Health Econ. 1999:8:41-51.

22. Morley D, Selai C, Schrag A, Thompson A, Jahanshahi M. Refinement and validation of the parental illness impact scale. Parkinsonism Relat Disord. 2010;16:181-5.

23. Papaioannou D, Brazier J, Parry G. How valid and responsive are generic health status measures, such as EQ-5D and SF-36, in schizophrenia? A systematic review. Value Health. 2011;14:907-20.

24. Ware JE, Kosinski M, Keller SD. SF-36 Physical \& Mental Summary Scores: A User's Manual. Boston: The Health Institute, New England Medical Center; 1994.
25. Ware JE, Kosinski M, Bayliss MS, McHorney C, Rogers WH, Raczek A. Comparison of methods for scoring and statistical analysis of SF-36 health profile and summary measures: summary of results from the medical outcomes study. Med Care. 1995;33:AS264-79.

26. Morley D, Jenkinson C, Doll H, Lavis G, Sharp R, Cooke P, et al. The Manchester-Oxford Foot Questionnaire (MOXFQ): development and validation of a summary index score. Bone Joint Res. 2013;2:66-9.

27. Morley D, Dummett S, Kelly L, Peters M, Dawson J, Fitzpatrick R, et al. The PDQ-Carer: development and validation of a summary index score. Parkinsonism Relat Disord. 2013;19:448-9.

\section{Submit your next manuscript to BioMed Central and take full advantage of:}

- Convenient online submission

- Thorough peer review

- No space constraints or color figure charges

- Immediate publication on acceptance

- Inclusion in PubMed, CAS, Scopus and Google Scholar

- Research which is freely available for redistribution 